\title{
Changes in gastronomy
}

\author{
Pavla Bureš ová ${ }^{1}$, Katarína Mrk vová2 ${ }^{2}$ Branis lav Dudić ${ }^{3 *}$ \\ ${ }^{1}$ College of Business and Hotel Management, Department of Gas tronomy and Hotel Industry, \\ Brno, Czech Republic \\ ${ }^{2}$ College of Business and Hotel Management, Department of Touris m and Hotel Industry, \\ Brno, Czech Republic \\ ${ }^{3}$ Comenius University, Faculty of Management, Bratis lava, Slovak Republic, and University \\ Business Academy, Faculty of Economics and Engineering Management, Novi Sad, \\ Republic of Serbia
}

\begin{abstract}
The paper provides an insight into factors influencing developments in gastronomy and catering services. The aim of the text is to identify the key elements affecting contemporary catering services including attendance at catering establishments, preferences in food selection, use of lunch menus, and adherence to hygiene standards in operational practice in food production. The first part of the survey shows the is sue of restaurant attendance during the working week. The second part examines the frequency of restaurant visitors, restaurant attendance at weekends and also the factors that influence the choice of food. The representative sample consists of the Czech National Panel, with respondents above 15 years of age. The data were obtained from 504 respondents (N 504). The third part of the investigation meets the most importantcriteria that affect the quality of services - hygiene standards in gastronomy focused on compliance with hygiene standards from the pers pective of hy giene control authorities. Factors for deciding the choice of food in restaurants and the frequency of restaurant visits were also examined.
\end{abstract}

Keywords: lunch menu, preferences in food selection, eating in restaurants, hygiene standards

JEL classification: L83, Z32

\section{Promene u gastronomiji}

Sažetak: Rad obezbeđuje uvid u faktore koji utiču na razvoj gastronomije i ugostiteljskih us luga. Cilj rada je da se identifikuju ključni elementi koji utiču na savremene ugostiteljske us luge, uključujući motive za posetu ugostiteljs kim objektima, preferencije prilikom izbora hrane, upotrebu menija i pridržavanje higijenskih standarda u operativnoj praksi $u$ proizvodnji hrane. Prvi deo is traživanja se bavi problematikompos ećenosti restorana tokom radne nedelje. Drugi deo istraživanja ispituje učestalost poseta restoranu, posećenost restorana vikendom i faktore koji utiču na izbor hrane. Reprezentativni uzorak čini Češki nacionalni panel, odnosno is pitanici stariji od 15 godina, sa ukupnimbrojem obrađenih podataka od 504 ispitanika (N 504). Treći deo istraživanja se odnosi na ispunjavanje najvažnijih kriterijuma koji utiču na kvalitet us luga - higijens ki standardi u gastronomiji iz ugla organa za higijensku kontrolu. Is pitivani su i faktori koji određuju izbor hrane u restoranima i učestalost poseta restorana.

* branislav.dudic@fm.uniba.sk 
Ključne reči: restorantski meni, preferencije u izboru hrane, ishrana u restoranima, higijenski standardi

JEL klasifikacija: L83, Z32

\section{Introduction}

Gas tron omy is understood from the point of view of the historical development of the human diet, connecting nations and communities with creativity, participants' abilities, raw materials, traditions, methods and recipes, new technologies that contribute to and influence the human diet. Gas tronomy is a discipline that involves many aspects. Ingredients are the basis of every diet, which, together with the methods of preparation, create a recipe for dishes with a unique taste and design. Everything takes place in an authentic environment that is shaped by terroir (climatic, geographical conditions and human skills). Cuisine is connected with localconditions, techniques, technologies, but the skills and abilities of the workers are the bas is of success. Mass gas tronomy cannot do without social and hygienic standards (Beranova, 2005; Burešová, 2014).

In his work "About gourmet and physiology of taste" Jean Anthelme Brillat-Savarin (17551826) des cribes theimportance of gastronomy: "The fates of nations depend on how they are nourished" (Brillat-Savarin, 1994, p. 125).

The key subject of the research is to map the reasons and frequency of attendance at gas tronomic establishments. The main objective of the res earch is to determine whether they comply with the standards that affect the quality of catering services - catering facility hygiene. The hypothesis is that restaurants fully comply with hygiene standards.

The introductory considerations of gastronomy are followed by the development of gastronomy through history as well the as analysis of the current state as a part of the theoretical background. The analytical part provides a view of the currentnutrition habits of the Czechs during the working week with a focus on catering services. This is followed by a survey about eating in res taurants during weekends and customer priorities that influence the choice of catering establishments. Other factors include customer safety connected with compliance with hygiene standards in catering services identified through inspections focused on hygiene compliance.

\section{The ore tical background}

\subsection{Development of gas tronomy throughout history}

The human diet has developed over millennia and has been influenced by traditions, geographical conditions, politics and culture. Fire has been used in food preparation for thousands of years and has fundamentally changed the human diet (Beranová, 2005; Wrangham, 2010).

Although open fires are still a way to prepare food, many other sophisticated technologies and methods are used today. Eating together has been an important part of physical and spiritual life that has shaped the culture of communities. The word "food" is used in a metaphorical sense more than 230 times in the Bible. Ancient civilizations used food as a pleasurable and effective means of facilitating negotiations of agreements and contracts (Morse, 1999).

Changes in diet were manifested differently in individual time periods. In prehistoric times, the diet included porridges of crushed corn, potages and grain pancakes (bread). Salt and 
wild herbs were used for seasoning food and the diet included a combination of meat and vegetable dishes (Beranová, 2001).

In antiquity, the diet included fruits and vegetables in addition to meat and cereals. A favourite meat dish was poultry - geese, ducks and hens. These times are known for organizing opulent celebrations and feasts with many sorts of delicacies, and people started to use various tableware made of precious metal. In the 1st century AD Marcus Gavius A picius created a recipe book called "De re coquinaria". The author was a chef and collector of recipes as well as a celebrated gourmet and the founder of the first culinary school. He was well known for preparing perfect sauces among other things (Sitwell, 2014).

The Roman diet comprised a diverse cuisine including game, pork, poultry, fish and seafood as well as various sorts of vegetables (broccoli, asparagus, lettuces, artichokes, leek, coriander etc.). Individual recipes were named after popular significant personalities, e.g. the piglet à la Marcus Aurelius. The Romans had their own bread recipe which has survived to the present day prepared with olives, herbs, spices and cheese. The Roman Consul and General Lucullus was renowned for fine dining. What distinguished his spectacular festive feasts fromother was the preparation of meals and the service. Later, at the end of the $15^{\text {th }}$ century, some new raw food products were imported to Europe fromAmerica and became essential for the cuisine of particular regions in Italy and Spain. Catherine de Medici, the Princess of Tuscany (1519-1598) contributed greatly to the glory of French gastronomy becau se she introduced to the French Court new raw food products, recipes, techniques, methods of food preparation and service, together with fine dining.

Later, French culinary masters (Escoffier, Carême) reorganized the kitchen workplace, introduced rules - personal and operational hygiene, changed the principles of menu creation, including recipe formulations, methods and techniques. In doing so they significantly influenced the further development of gastronomy in ways that have persisted to the present day (Burešová, 2014).

Culinary techniques and methods have evolved over time, including kitchen equipment, kitchenware and meal serving. An open fireplace has been used to heat food from the beginnings of gastronomy (Wrangham, 2010). Large pieces of meat were roasted in the fireplace and cooked food was prepared in pot-like kettles, which hung above the fireplace. Pies and bread were baked in wood heated furnaces (Beranová, 2005; Feyfrlíková, 2015; Pešek, 2007).

An important part of the human eating experience is the social environment of when and how food is consumed, including the rituals and customs of the individual societies. From the beginning, diet has been influenced by a region's local traditions, culture ethnicity and history. The basis of good food preparation has always been the origin of the food, the freshness of ingredients and the processing methods (recipe, culinary methods, suitable techniques and technologies). In the 18th century the cooks knew that the best recipe is the one that uses the right proportion and quantities of the individual ingredients (Beranová, 2001; Brillat-Savarin, 1994; Sitwell, 2014).

Throughouthuman development eating has adapted to geographical, cultural, social and political changes. From the perspective of economics, entrepreneurship is the main tool for economic development of each state (Mocarnikova et al., 2018). The emphasis is on the sensory characteristics of food - appearance, flavouring and the taste of meals. Today's menu card builds on traditional procedures of hygiene standards which were known in aris tocratic residences as early as the Middle Ages. The standards for creating menus are based on natural elements: the element of earth was represented by bitter taste, the element 
of water by acidity, wind by s weetness and bitterness, and fire by the taste of salt and pepper (Hrdlička, 2000; Pešek, 2007).

\subsection{Analysis of the current state}

Over the past thirty years there have been radical changes in the field of gastronomy and many new trends and new concepts have merged. At present traditional (regional) gastronomy is complemented by many global and ethnical elements. Today's g as tronomy builds on the principles of a gastronomic trend called "nouvelle cuis ine" which emerged in France in the 1970s. (Sitwell, 2014, p. 205). New culinary methods and improved technologies of food production and preservation are constantly emerging, in today's technology enabled environment e.g. shock freezing, vacuum cooking, induction cooking. New chefs, managers and the media focus on wealthy clientele who want to "stand out from crowd" and prefer traits such as leanness, lightness, health, pleasure and originality. We can meet consumers with many different gastronomic preferences. Sociologis ts have divided them into categories, for example according to their consumption of ready-cooked food. Conservative consumers do not believe in new trends (Alimpić \& Perić, 2019; Hajiyeva, 2018) and they prefer local and traditional food. Intellectually focused consumers emphas ize price and nutritional value. Ecologically and health-oriented consumers prefer bio food (Seočanac, 2019). Gourmet consumers are those who "eat out" and look for food and drink in accordance with "the soil" (Freedman, 2008).

Various types of cooker technologies are available, induction, glass-ceramic, electrical or gas and open fire. Food properties such as its strength, rigidity, fragility, flavour, consistency, shape and temperature are essential to the taste sensation of foods and drinks (This, 2006).

The design of dis hes for serving foods and drinks has also changed - we use s mall and large plates, divided plates, and various layered arrangements of plates and bowls of various shapes (squared, round, oval) etc. Over the last decade there has been growing interest in gas tronomy which is reflected in the media. Marketing - involves the creation of valuable, relevant and consistent content to acquire and retain customers (Poráziková \& Vojtechovský, 2016). Chefs and recipes are the subject of many books, TV shows and sharing on social media. The convenient use of marketing tools helps to promote this way of entrepreneurship (Peraceket al., 2017). The attitude to food consumption is changing and it influences the number of people that visit gastronomic establishments.

\section{Mate rials and methods}

The objective of this study is to map the key aspects that influence currentcatering services. A sub-objective is the comparis on of selected elements at the menu level of catering services and the prerequisites for potential development. The representative sample consisted of the Czech National Panel, respondents aged 15+. The data were obtained from 504 res pondents (N 504).

The primary and secondary data come from the quoted literary sources, studies and available information. This is followed by the comparative analysis of the frequency and popularity of restaurants and cafés using the latest data by the prestigious research agencies Nielsen Atmos phere, Incoma Gfk, Edenred. These were then summarized and transferred in to tables. The analysis relates to the comparis on of lunch purchases in gas tronomic establishments on weekdays and at weekends. Food choice decision-making factors and the frequency of food visits in restaurants were also examined. 
Hygiene standards were analysed, compared, demons trated and evaluated via information available on regional public health network websites. The aim was to detect the most common non-compliance is sues in hy giene observance and HACCP rules in contemporary gastronomical practice.

\section{Results}

The first part of the analys is focuses on the attendance at gastronomic establishments in order to buy available lunch menus. Researching eating habits during working hours implied obtaining responses across Europe. The second part examines the frequency of restaurant visitors, restaurant attendance at weekends and researching the factors that influence food choice decisions. The third part examines meeting hygienic standards in gastronomy.

The research monitored respondents throughout Europe who consume food during their working hours. The results showed that almost half of the examined Czechs eat dinners in restaurants (49\%) and 5\% of them eat at fast food facilities. On the other hand, $60 \%$ of Belgian working people and $59 \%$ of Germans eat in some kind of eating establishment. In the Czech Republic 30\% employees started to use the space reserved for eating during last year as well. On the other hand, $20 \%$ of Slovak people are leaders in eating at the working table (Edenred, 2020).

Table 1 shows the percentage of Czech people aged 15+ (total 504 respondents) who used catering services for eating during an ordinary working week. Around a quarter $(24 \%)$ of the respondents never eat in restaurants. The same number have lunch in restaurants during a working week ( $11 \%$ of themevery day and $13 \%$ of them almost every day). The other $26 \%$ eat in restaurants several times a month and the same number rarely eat there.

Table 1: How often are restaurants used for eating lunch during working weeks

\begin{tabular}{|c|c|}
\hline Frequency & Precentage (\%) \\
\hline Several times a month & 26 \\
\hline Rarely & 26 \\
\hline Never & 24 \\
\hline Every day & 13 \\
\hline Almost every day & 11 \\
\hline
\end{tabular}

Source: Niels en Atmosphere, 2019

Table 2 shows the factors which influence the choice of lunch venue - as monitored by Edenred Resource company. The majority of respondents choose their lunch venue according to what they want to eat at the time (80\%), almost half of the respondents $(47 \%)$ are influenced by the speed of service and only $44 \%$ of the respondents are interested in the nutritional value. Aquarter of the respondents are influenced by the size of portions. The least important is the price of food for the consumers (with regards to lunch menus that are still very popular in the Czech Republic). 
Table 2: What is the priority in the choice of lunch in restaurants

\begin{tabular}{|c|c|}
\hline Factors influencing the choice of lunch & Precentage (\%) \\
\hline What I want to eat & 80 \\
\hline The speed of service & 47 \\
\hline Nutritional value & 44 \\
\hline The size of a portion & 25 \\
\hline The price & 20 \\
\hline
\end{tabular}

Source: Edenred, 2020

Previous research shows sizable restaurant attendances during lunch time because the Czechs are used to eating lunch menus. The following data were reported by the Gfk agency using an interview survey method (according to the task of the Minis try of Regional Development) on a representative sample of respondents over 18 years of age, to record restaurant attendance. The respondents did not participate in any other survey in the period of six months and they went for lunch or dinner to a catering facility in the Czech Republic which they chose. Table 3 shows frequency of going to restaurants for lunch or dinner, indicating that $43 \%$ of respondents visit restaurant once a week, while only $19 \%$ attend restaurants several times a week.

Table 3: The frequency of going to restaurants for lunch or dinner

\begin{tabular}{|c|c|}
\hline Frequency & Precentage (\%) \\
\hline Minimum once a week (les s often) & 43 \\
\hline Once a month & 25 \\
\hline Once in two weeks & 24 \\
\hline Several times a week & 19 \\
\hline
\end{tabular}

Source: Incoma Gfk, 2016

Table 4 shows restaurant attendance during weekends. Nielsen Atmosphere also analysed how and where the Czechs go to eat. The surveyed panel shows the answers of 504 respondents: only $3 \%$ of respondents go to res taurants every weekend, $58 \%$ of them rarely go to restaurants, $24 \%$ go several times a month and less than $15 \%$ never go to restaurants. Working days show other results.

Table 4: Lunch in restaurants during weekends

\begin{tabular}{|c|c|}
\hline Frequency & Precentage (\%) \\
\hline Every weekend & 1 \\
\hline Almost every weekend & 2 \\
\hline Several times a month & 24 \\
\hline Rarely & 58 \\
\hline Never & 15 \\
\hline
\end{tabular}

Source: Nielsen Atmosphere, 2019 
Contemporary gastronomy is based on uniqueness, originality, brand, safety and quality. Hygiene is the key forensuring a safe meal and a quality service. Compliance with hygiene standards is an essential component of the production process. The defined principles of hygiene for catering facilities are part of mandatory regulations, yet in practice there are problems that present a public health hazard and represent a safety risk for customers. According to the research of Incoma agency 93\% customers prioritize cleanness and hygiene standards in their choice of a restaurant (Incoma, 2016). Typical examples of violations of the hygiene rules can be found in audits carried out under the supervision of regional hy giene offices. From January to November 2018 the regional hygiene offices carried out 20713 audits in total at 18337 catering facilities including restaurants, diners, cafés, food factories, canteens and cafeterias (Table 5).

Table 5: Hygiene audition results in catering facilities January - November 2018

\begin{tabular}{|c|c|}
\hline Number of audited facilities & 18337 \\
\hline Number of controls & 20713 \\
\hline Closing of facilities & 34 \\
\hline Suspension of operations & 113 \\
\hline Sanitations & 334 \\
\hline Disposals of food & 106 \\
\hline Type and number of measures imposed & 587 \\
\hline Number of proposed penalties & 5480 \\
\hline Height of proposed penalties & 19.710 .700 CZK \\
\hline
\end{tabular}

Source: MZCZ, 2019

According to the inspection results the most frequent shortcomings are: negligent cleaning and operational inconsistencies with the systembased on HACCP operations. Other failures are linked to the facility's building and technical shortcomings, indications of health problems after food consumption, labelling of ready-to-cook and semi-finished food, the permanent procedures based on HACCP principles, and the food expiry date (HSHMP, 2019; KHSJMK, 2019; KHSČK, 2019).

\section{Discussion}

The research objectives were focused on the frequency and reasons for visiting restaurants. Several studies analysed the frequency of restaurant visits (Bhutani et al., 2016; Close et al., 2016) and came up with similar findings as ours. In these studies, the attendance in sit-down restaurants was found to be between $40 \%$ and $60 \%$, once again confirming our results. In comparison with the results from the USA where $37.2 \%$ respondents were using fast-food services (Close et al., 2016), our results showed that only $5 \%$ of respondents vis it res taurants that offer that kind of services. The main objective of the research was to determine whether restaurants meet hygiene standards that can affect the quality of catering services. It was assumed that the restaurants fully comply with hygiene standards. The hypothes is was not confirmed by the hygienic audit.

The results of the survey show that customers perceivequality and freshness as key factors in the choice of restaurant (Incoma, 2016; Nielsen Atmosphere, 2019). Kitchen philosophy is the reflection of each chef's personality. The originality of recipes lies in using high-quality 
seasonal (local) raw materials, and food preparation techniques. There are changes in new technologies, marketing and offerings connected with on line sales and massive use of social networks. One of the aspects which influence the restaurants attendance (according to research) is an attractive menu which attracts consumers, quick service, nutritionalvalue, and portion size. The as pect of price has moved to the last place.

According to researches by Incoma (2016) and Nielsen Atmosphere (2019), it can be concluded that attractive menus, distinctive choice of food and drinks, healthiness of food, and fast customer service are an indication of high quality. Hygiene audits of catering facilities reveal deficiencies in the protection of raw materials against contamination, storage of food and raw materials for production, general building and technical requirements for manufacturing facilities, operational hygiene, marking unfinished meals, and adhering to HACCP procedures.

The main aim of the hygiene rules is to ensure a high level of consumer protection with regards to food safety. Operators must ensure food safety at all stages of handling food, substances, raw materials, semi-finished products. The direct responsibility of the operator for the safety of food is emphasized - the operator must be able to demonstrate the awareness of potential ris ks and at the same time effective manage ment of the ris ks - e.g. the practical implementation of any of the HACCP-based principles. Emphas is is placed on compliance with temperature chain requirements - what has to stay warm (or cold) must remain warm (or cold). There is also a requirement to manage traceability, i.e. the ability of the operator to prove the origin of the processed raw materials by delivery notes or invoices. Legislation determines the minimal requirements and conditions for working with food. Compliance requirements should be checked not only by official audits but also by senior executives who are obliged to do it. This means the implementation of self-evaluation (selfcheck) system. Operators of catering facilities should implement and carry out safety food programmes and procedures based on HACCP rules (Burešová, 2014; Voldřich \& Jechová, 2006).

The foundation of contemporary and future gastronomy is an attractivemenu based on high quality raw materials, suitable technologies, skilled chefs and hygiene standards aimed at safety and consumer satisfaction. There are changes in digital technologies which can influence the attractiveness of the offer, facilitate or simplify processes, and support the patronage of catering venues. According to HOREKA the new trends of paying by QR codes will replace cash payments. New concepts for producing and distributing food are developing through shared services like Uber Eats and Dotykačka (touch-on). Other technological benefits are applications such as JIDLOV where the aim is to sell unused food and meals from shops, restaurants, bakeries to avoid wastage. The concept of mono-thematic restaurants is developing, and they are successful because they handle their products well and have low operating costs. In the field of beverage gastronomy new drinks are being created to meet the needs of customers. Special kinds of beer are gaining popularity together with spirits and localfermented drinks and also new wine styles with low alcohol, flavoured wines etc. Tea (quality tea leaves) is seeking a place in bars, res taurants and tearooms. Coffee shops are increasingly offering alternative sorts of coffees in addition to espresso. New roasting companies that roast quality selected coffee from different places of orig in (terroir) are emerging (Horeka, 2019).

\section{Conclusion}

The skills that the man has allow growing and cultivating different foods depending on the environment in which it is consumed. Techniques, recipes, technologies, standards and raw materials for food preparation are changing due to cultural, social, global and economical 
factors. Today's diet is influenced by many factors ranging from traditional to multicultural influences, fashion trends and scientific knowledge. The sensory perception of food is the key factor in the choice and evaluation of food. This is linked to the consumer's preferences in food choice as well as the choice of eating facility. The aim of the study was to identify factors which influence contemporary gastronomy. The results of the analys is show the current situation regarding patronage of gas tronomical facilities which is very high in the Czech Republic compared to other countries, mainly due to the attractive offer of lunch menus. Monitoring and compliance with food hy giene standards in catering facilities form a part of mandatory regulations, although in practice there have been some problems of noncompliance that are hazardous to health and represent a safety risk for the customers, in food storage and meal preparation.

\section{References}

1. Alimpić, S., \& Perić, N. (2019). Različiti oblici impulsivnog ponašanja potrošača [Different forms of consumers' impulsive buying behavior]. Anali Ekonomskog fakulteta u Subotici, 55(42), 49-63. https://doi.org/10.5937/AnEkSub1942049A

2. Beranová, M. (2001). Tradični české kuchařky: jak se vařilo před M.D. Rettigovou [Traditional Czech cookbooks: How they cooked before M.D. Rettigovou]. Praha, Czech Republic: Libri, 279.

3. Beranová, M. (2005). Jídlo a pití v pravěku a ve středověku [Food and drink in prehistoric and medieval times]. Praha, Czech Republic: Academia.

4. Bhutani, S., Schoeller, D. A., Walsh, M. C., \& McWilliams, C. (2016). Frequency of eating out at both fast-food and sit-down restaurants was as sociated with high body mass index in non-large metropolitan communities in midwest. American Journal of Health Promotion, 32(1), 75-83. https://doi.org/10.1177/0890117116660772

5. Brillat-Savarin, J. A. (1994). O labužnictví: Fyziologie chuti: Kniha milovníků dobrých jídel. [About gourmet: Taste physiology: A book of good food lovers]. Praha, Czech Republic.

6. Burešová, P. (2014). Vybranékapitoly zhotelnictví a gastronomie [Selected chapters from hotel and gastronomy]. Praha, Czech Republic: Wolters Kluwer.

7. Close, M. A., Lytle, L. A., \& Viera, A. J. (2016). Is frequency of fast food and sit-down restaurant eating occasions differentially associated with less healthful eating habits? Preventive Medicine Reports, 4, 574-577. https ://doi.org/10.1016/j.pmedr.2016.10.011

8. Edenred (2020). Stravenky Ticket Restaurant, benefity, dárkové poukázky [Ticket Restaurant meal vouchers, benefits, gift vouchers]. Retrieved February 28, 2020 from https://www.edenred.cz/

9. Feyfrlíková, M. (2015). Kuchyně pozdního středověku [Late middle ages cuisine]. Praha, Czech Republic: Grada Publishing.

10. Freedman, P. H. (Ed.). (2008). Jídlo: dějiny chuti [Food: historyoftaste]. Praha, Czech Republic.

11. Hajiyeva, L. (2018). The study of consumer preferences of young tourist. Ekonomika, 64(3), 37-46. https://doi.org/10.5937/ekonomika1803037H

12. Horeka (2016). Zpravodajstvi ze světa pohostinství [News from the world of hospitality]. $\begin{array}{llll}\text { Retrieved November } & 27, & \text { from }\end{array}$ https://www.horekaweb.cz/category/zpravodajstvi/kavarny/

13. Hrdlička, J. (2000). Hodovní stůl a dvorská společnost: Strava na raně novověkých aristokratických dvorech v českých zemich (1550-1650) [Banquet table and court society: Diet at the early modern aristocratic courts in the Czech lands (1550-1650)]. České Budějovice. 
14. Hygienická stanice hlavního města Prahy (HSHMP) (2019). Kontroly stravovacích zař́zeni naúzemi hlavního města Prahyv zářri 2019 [Inspections of catering facilities in the City of Prague in September 2019]. Retrieved October 25, 2019 from http://www.hygpraha.cz/dokumenty/kontroly-stravovacich-zarizeni-na-uzemi-hlavnihomesta-prahy-v-zari-2019-4403_4403_425_1.html

15. Incoma GfK (2016). HoReCa \& Industry. Retrieved October 26, 2019 from https://incoma.cz/hos pitality-and-b2b/

16. Krajská hygienická stanice Jihomoravského kraje (KHSJMK) [Regionalhygiene station of the South moravian region] (2019). Retrieved January 28, 2020 from http://www.khsbrno.cz/

17. Ministerstvo zdravotnictva České Republiky (MZCZ) [Ministry of Health of the Czech Republic] (2019). Retrieved October 26, 2019 from https ://www.mzcr.cz/

18. Mocarnikova K., Mucha B., \& Peracek, T. (2018). The importance and position of public company in the Slovak business law. 31 st International-Business-InformationManagement-Association Conference (pp. 3494-3502). Milan, Italy.

19. Morse, K. (1999). Biblická hostina: Pokrmy ze Svaté zemé [Biblical feast: Dishes from the Holy Land]. Praha, Czech Republic: Volvox Globator.

20. Nielsen Atmosphere (2019). Retrieved October 25, 2019 from https://www.nielsenadmosphere.eu/

21. Peracek, T., Noskova, M., \& Mucha B. (2017). Special characters of family businesses in the Slovak Republic. 24th International Scientific Conference on Economic and SocialDevelopment-Managerial Issues in Modern Business (pp. 260-266). Warsaw, Poland.

22. Pešek, P. (2007). Ruská kuchyně v proměnách doby: Gastro-etno-kulturní studie [Russian cuisine in the changing times: gastro-ethno-cultural study]. Červený Kostelec: Pavel Mervart.

23. Poráziková E., \& Vojtechovský J. (2016). Trends in e-business and their application in development of SMEs in Slovakia. Praha, Czech Republic: Newton College.

24. Seočanac, M. (2019). Are LOHAS consumers a perspective tourism segment? Economics of Sustainable Development, 3(2), 29-38. https://doi.org/10.5937/ESD1902029S

25. Sitwell, W. (2014). Dějiny jídla ve 100 receptech [History of food in 100 recipes]. Praha, Czech Republic: Argo.

26. This, H. (2006). Molecular gastronomy: Exploring the science offlavor. New York: Columbia University Press.

27. Voldřich, M., \& Jechová, M. (2006). Bezpečnostpokrmů v gastronomii-malé a střední provozovny [Food safety in small and medium-sized establishments]. Praha, Czech Republic: Ceské a slovenské odborné nakladatelství.

28. Výsledky kontrol stravovacích zařizeni KHS, leden-listopad 2018 (KHSČK) [Results of inspections of KHS catering establishments, January-November 2018]. (2019). Retrieved November 1, 2019 from https://www.mzcr.cz/Verejne/dokumenty/vysledky kontrol-stravovacich-zarizeni-khs-leden-listopad-2018_16462_3365_5.html

29. Wrangham, R. W.(2010). Catching fire: How cooking made us human. London, United Kingdom: Basic Books.

Received: 31 March 2020; Sent for revision: 16 April 2020; Accepted: 11 May 2020 